\title{
Sivistystyön olemuksellinen epämuodikkuus
}

A

ikuiskasvatuksen Tutkimusseuran tavoitteena on ollut jo pitkään käynnistää keskustelutilaisuuksien sarjaa aikuiskasvatuksen monilla toimintakentillä. Tällaisia kenttiä ovat esimerkiksi avoin korkeakoulu, työelämän henkilöstökoulutus ja kehittäminen, työvoimapoliittinen koulutus- ja ohjaustoiminta, monet kolmannen sektorin toimintamuodot sekä ammatillinen aikuiskoulutus laajasti ymmärrettynä. "Vapaan sivistystyön paikka

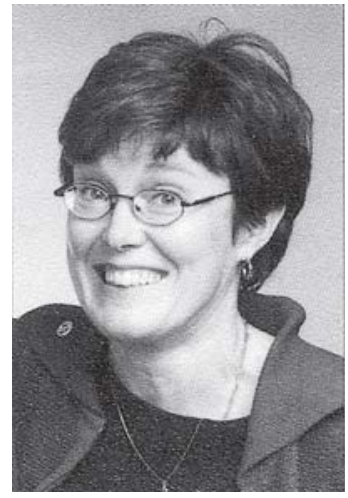
ja merkitys tässä ajassa" -tilaisuus oli ensimmäinen tässä lajissa ja se järjestettiin aikuiskasvatuksen ydinalueella eli vapaassa sivistystyössä. Helsingin suomenkielinen työväenopisto tarjosi uuden johtavan rehtorin Taina Törmän ystävällisellä myötävaikutuksella nostalgiset puitteet tapaamiselle upeine lauluesityksineen, jotka kertoivat työväenopiston perustoiminnasta. Olemme usein Tutkimusseurassa keskustelleet siitä, miksi vapaa sivistystyö mieltyy valtamediassa edelleen helposti hieman pölyttyneeksi toimintamaastoksi. Filosofi ja kriittisen korkeakoulun toiminnanjohtaja Eero Ojanen sai meidät ymmärtämään, että sivistystyö on olemukseltaan aina epämuodikasta ja epäajankohtaista. On oikeastaan kovin turhaa kysyä, kannattaako sivistys. Ennemmin tulisi kysyä, kannattaako talous.

Vapaa sivistystyö leimautuu myös helposti valtajulkisuudessa turhanaikaiseksi hömpäksi (ks. esim. Demari 7.9.07 tai Ilta-Sanomat 14.9.07). Osanottajat ihmettelivät yhdessä, miksi pitää pyydellä anteeksi toimintaa, joka "tarjoaa innostusta ja hyvinvointia monella tasolla myös niille ihmisille, jotka kiivaasti toimivat yhteiskunnan rattaissa, kuten esimerkiksi keski-ikäiset naiset”. Jostain syystä keski-ikäisten ja vanhojen naisten harrastaminen määrittyy suomalaisessa julkisuudessa hömpäksi, oli se sitten mitä tahansa. Esimerkiksi joogan kaltainen opintotoiminta, joka antaa elämälle merkitystä ja auttaa jaksamaan hektisessä työelämässä, on luonut vuosikymmeniä perustaa terveydelle, sosiaaliselle luottamukselle ja tasa-arvoisen kohtaamisen eetokselle. Vapaan sivistystyön tiloissa tapaavat nuoret, van- hat, työttömät, työlliset, naiset ja miehet yhteisen harrastamisen maastossa. Ymmärtävätköhän poliittiset päättäjät oikeastaan ollenkaan, miten "edullinen”, keskeinen hengissä selviämisen ja ennaltaehkäisyn positiivinen tukirakenne vapaa sivistystyö tässä ajassa oikeastaan Suomessa on. Määrittelimme tilaisuudessa myös harrastuksia, joita voitaisiin väittää miesten hömpäksi. Löysimme karaoke-laulupiirin, johon osallistuu myös monia miehiä. Kansalaisopiston rehtori tosin kertoi, että innokkain karaoke-piirin miespuolinen harrastaja jatkoi harrastustaan myöhemmin klassisen yksinlaulun parissa. Eli mikä taas olikaan hömppää ja mikä oli sivistystä?

Kirjastoalan johtava asiantuntija tiivisti vapaan sivistystyön uudenlaisen ajankohtaisuuden seuraavasti: Millä tahansa harrastuksen alalla on nykyään huomattavan paljon varsin taitavia amatöörejä, esimerkiksi sellaisilla alueilla kuten tanssi, musiikki tai käsityö. Nämä harrastajat hankkivat näin itselleen henkireiän muuten niin kovin stressaavaan elämään. Vaativan työnteon ja vaativan harrastuksen välillä on elävä suhde. Rankka työ vaatii rankat huvit. On mentävä syvälle harrastukseen, jotta se todella irrottaisi. Hän kertoi itse oppineensa laajempaa ilmaisua laulamalla, joka on ollut myös hyödyksi vaativassa johtamistyössä.

Lopuksi vielä: Liittykää Aikuiskasvatuksen Tutkimusseuran jäseniksi (www.protsv.fi/ats). Tarvitsemme uusia aktiivisia jäseniä ja jäsenyys on myös teidän etunne. Saatte näin Aikuiskasvatus-lehden vuosikerran ilmaiseksi ja tietoa monista mielenkiintoisista julkaisuista ja tilaisuuksista. Voitte myös itse ottaa yhteyttä seuran sihteeriin ja esimiehiin, jos haluatte omalle kentällenne aikuiskasvatukseen liittyviä keskustelutilaisuuksia.

\section{Karin Filander}

Kirjoittaja on Aikuiskasvatuksen Tutkimusseuran varaesimies. 